\title{
Nurmen satofysiologia nurmien sadon määrän ja ruokinnallisen arvon perustana
}

\author{
Perttu Virkajärvi ${ }^{1)}$, Kirsi Pakarinen ${ }^{1)}$, Maarit Hyrkäs ${ }^{1)}$, Jyri Savolainen ${ }^{1)}$, Mervi Seppänen ${ }^{2)}$, Outi \\ Manninen ${ }^{3)}$, Mika Isolahti ${ }^{4}$ ja Marketta Rinne ${ }^{5}$ \\ ${ }^{1)}$ MTT Kotieläintuotannon tutkimus, Halolantie 31 A, 71750 Maaninka, perttu.virkajarvi@mtt.fi \\ ${ }^{2)}$ Helsingin yliopisto, Maataloustieteiden laitos, Latokartanonkaari 5-7, 00014 Helsingin yliopisto, \\ mervi.seppanen@helsinki.fi \\ ${ }^{3)}$ MTT Biotekniikka- ja elintarviketutkimus, E-talo, 31600 Jokioinen, outi.manninen@mtt.fi \\ ${ }^{4)}$ Boreal Kasvinjalostus Oy, 31600 Jokioinen, mika.isolahti@boreal.fi \\ ${ }^{5)}$ MTT Kotieläintuotannon tutkimus, H-talo, 31600 Jokioinen, marketta.rinne@mtt.fi
}

\section{Tiivistelmä}

Nurmet ovat sekä taloudellisesti että maankäytöllisesti merkittävä tuotantomuoto. Tästä huolimatta niiden sadonmuodostuksen sisäisistä prosesseista tiedetään Suomessa varsin niukasti. Yleensä sadonmuodostus kuvataankin vain massan määrän ja ruokinnallisen arvon muutoksina ajan tai lämpötilasumman funktiona. Tässä tutkimuksessa selvitettiin keskeisimmät sadonmuodokseen vaikuttavat prosessit sadon määrän ja ruokinnallisen arvon kannalta. Tutkimuksen kohteena oli erityisesti timotei sekä kasvutavaltaan timoteistä huomattavasti poikkeava ruokonata.

Tutkimuksen aineisto koostuu pääosin kahdesta osasta: ruokonadan ja timotein kasvuprosessien vertailusta MTT:n Maaningan toimipisteessä vuosina 2006 - 2007 ja timotein laatujalostusaineistosta valittujen kloonien vertailusta Maaningalla 2008 - 2009. Ensimmäisessä kokeessa määritettiin satofysiologisia parametreja laajasti ja timoteikloonien osalta keskityttiin korrenmuodostukseen ja versotyyppijakaumaan. Molemmissa kokeissa määritettiin ruokinnallinen arvo, mm. sulamaton kuitu (iNDF) ja sulavan orgaanisen aineksen pitoisuus (D-arvo) koko sadosta ja kasvinosittain (lehdet, korret, kukinto, kuolleet kasviosat) joko kemiallisin määrityksin (MTT Jokioinen) tai NIR-määrityksin (Boreal Kasvinjalostus Oy). Lisäksi korsi- ja lehtimateriaalista tarkasteltiin niiden anatomista rakennetta safraniini- ja Mäule-värjättyinä valomikroskopialla Helsingin yliopistossa.

Tärkeimmiksi prosesseiksi valikoituivat korrenmuodostus, versominen sekä lehtien muodostuminen ja kuoleminen. Timotei ja ruokonata poikkeavat toisistaan yleisesti kasvuprosessien osalta lähes kaikin tavoin, jopa lehtien sulavuuteen vaikuttavien ominaisuuksien osalta. Timotein osalta merkittävimmäksi sadonmuodostusparametriksi havaittiin korrenmuodostus ja laatuparametriksi erot versotyyppien sulavuudessa ja kuolleen solukon määrä. Versotyyppijakauma pääsadon korjuuhetkellä selittää hyvin kasvilajien väliset erot jälkikasvussa. Lisäksi timotein versotyypit poikkeavat ratkaisevasti toisistaan lehtien kasvu- ja kuolemisnopeuksien osalta. Lehtien osuus sadossa selitti hyvin D-arvoa pääsadossa, mutta jälkisadossa kuolleen solukon määrä oli ratkaisevampi. Ruokonadan sato koostui etenkin jälkisadossa lähes täysin VEG-versoista ja siten lehtien osuus sadosta oli korkeampi kuin timoteillä.

Asiasanat: timotei, ruokonata, säilörehu, verso, rehun ruokinnallinen arvo, D-arvo, satofysiologia 


\section{Johdanto}

Suomessa yli puolet maatalouden tuloista on peräisin nurmirehuihin perustuvasta maidon ja naudanlihan tuotannosta, ja noin 80 \% elintarvikkeita jalostavan teollisuuden työpaikoista on maidonja lihanjalostuksen piirissä; lihanjalostuksen osalta luku sisältää siat ja siipikarjan. Karjatilojen huomattavan työllistämisvaikutuksen, runsaan tuotantopanoksien käytön ja karjataloustuotteiden korkean jalostusarvon vuoksi nurmiviljelyllä on suuri yhteiskunnallinen ja maaseudun elinvoimaisuutta ylläpitävä merkitys.

Nurmen suuresta taloudellisesta ja ympäristöllisestä merkityksestä huolimatta nurmikasvien satofysiologiaa tunnetaan Suomessa heikosti. Ulkomaiset satofysiologiset tutkimukset soveltuvat huonosti Suomeen, koska kasvilajit, kasvuolosuhteet ja nurmien käyttötarkoitukset ovat erilaiset ja pohjoismaisia tuloksia on vielä niukasti. Nurmisato koostuu yksittäisistä versoista, joiden satofysiologiset prosessit, kuten versojen ja lehtien syntyminen ja kuoleminen, korren muodostuminen ja korren tukirakenteen jäykistyminen lignifikaation seurauksena, määräävät sekä sadon määrän että sen ravitsemuksellisen arvon. Satofysiologisten prosessien parempi tunteminen mahdollistaa lyhyellä aikavälillä viljelytekniikan kehittymisen (mm. sadonkorjuun ajoitus, lajikevalinta) sekä pidemmällä aikavälillä uusien lajikkeiden kehittämisen ja uusien työkalujen käyttämisen tässä kehitystyössä. Näistä syistä käynnistettiin NURFYS-hanke MTT:n strategisilla (2006-2008) ja MMM:n MAKERA:n (2007-2009) tutkimusvaroilla. Hankkeessa on pureuduttu aiempaa syvemmälle nurmen kasvun dynamiikkaan ja kasvuprosessien säätelyyn yhdistäen tähän uusimmat ravitsemuksellisen arvon parametrit. Työssä on käytetty timotein ja ruokonadan valtalajikkeita sekä Boreal Kasvinjalostus Oy:n erityisiä ns. laatuaineiston klooneja (eliittikloonit). Työtä on tehty yhteistyössä MTT:n, Helsingin yliopiston ja Boreal Kasvinjalostus Oy:n kanssa. Tuloksia on esitelty jo aiemmin timotein osalta (Pakarinen ym. 2008) ja tässä esitetään keskeiset yhteenvetotaulukot aineiston kenttäkokeiden osalta.

\section{Aineisto ja menetelmät}

\section{Timotei ja ruokonata}

Kenttäkokeet suoritettiin MTT:n Maaningan toimipisteessä vuosina 2006 - 2007. Koe perustettiin vuonna 2005 kolmena kerranteena käyttäen Tammisto II -timoteitä ja Retu-ruokonataa. Nurmivuosina 2006 ja 2007 koeruudut saivat sekä keväällä että jälkisadolle $90 \mathrm{~kg} \mathrm{ha}^{-1} \mathrm{~N}$ sekä suositusten mukaisen P- ja K- lannoituksen. Niitot tehtiin $7 \mathrm{~cm}$ sänkikorkeuteen. Pääsadon niitot ajoitettiin aikaiseen, keskimääräiseen ja myöhäiseen kehitysvaiheeseen 7 vrk välein. Keskimääräiseksi arvioituna pääsadon niittoajankohtana niitettiin myös jälkisadon niittoja varten tarkoitetut koeruudut, joilta suoritettiin jälkisadon niitot 4, 6 ja 8 viikkoa pääsadon niiton jälkeen.

Jokaisena niittoajankohtana koeruuduista otettiin $30 \times 30 \mathrm{~cm}$ osanäyte leikkaamalla kasvusto maan pinnasta, koska muutoin versotyyppejä ei olisi voitu erottaa toisistaan. Leikkuukorkeus vaikuttaa luonnollisesti saatuihin lukuarvoihin, mutta vertailu niittojen ja kasvilajien välillä on validi. Näyte eroteltiin ensin eri versotyyppeihin (vegetatiivinen, VEG; vegetatiivinen elongoituva, ELONG ja generatiivinen, GEN), irralliseen elävään ja irralliseen kuolleeseen solukkoon sekä rikkakasveihin. Versoluokittelu tehtiin seuraavasti: 1) VEG: ei aitokortta vaan pseudokorsi, ei näkyviä tai tunnustelemalla havaittavia solmuja; 2) ELONG: aitokorsi, jossa vähintään yksi näkyvä tai tunnusteltaessa havaittava solmu, mutta ei näkyvää tai lehtitupessa tuntuvaa kehittyvää kukintoa; 3) GEN: aitokorsi, jossa solmuja ja näkyvä tai lehtitupessa tuntuva kukinto. Versotyypit eroteltiin edelleen korteen (sisältäen pseudokorren ja lehtitupet), elävään lehtilapaan, kukintoon ja versoon kiinnittyneeseen kuolleeseen solukkoon. Kaikki fraktiot kuivattiin $+60{ }^{\circ} \mathrm{C}$ :ssa $40 \mathrm{~h}$. Fraktioiden tuhkan, raakavalkuaisen (RV), kuidun (neutraalidetergenttimenetelmällä), ja ligniinin pitoisuudet sekä orgaanisen aineen sulavuus (OAS; pepsiini-sellulaasimenetelmä; Nousiainen ym. 2003) määritettiin MTT:n laboratoriossa standardimenetelmin. D-arvo $\left(\mathrm{g} \mathrm{kg}^{-1} \mathrm{ka}\right.$ ) laskettiin OAS:sta kertomalla se orgaanisen aineen pitoisuudella (1000 - tuhka, $\mathrm{g} \mathrm{kg}^{-1} \mathrm{ka}$ ). Sulamaton kuitu (iNDF) määritettiin 12 vrk:n pötsi-inkubaatiolla nailonpusseissa karkearehuvaltaisella ruokinnalla olevia lehmiä käyttäen. Eri versotyyppien tuottamat kuiva-ainemassat ja niiden rehuarvot laskettiin saatujen paino-osuus- ja rehuarvotulosten perusteella. 
Jälkisadon versonkehityksestä kerättiin havaintoja merkitsemällä yksittäisiä versoja ennen pääsadon niittoa. Jälkisatoon kehittyneistä versoista havainnoitiin $\mathrm{mm}$. lehtien ilmestymis- ja kuolemistaajuutta, lehtien pituuskasvua ja lakastumista sekä sivuversojen ilmestymistä ja versokuolemia.

\section{Eliittikloonit}

Boreal Kasvinjalostus Oy:n timotein klooniaineistoon perustuva koe suoritettiin MTT:n Maaningan toimipisteessä vuosina 2008 - 2009. Kokeessa oli mukana 11 erilaista timoteikloonia, niiden molemmat vanhemmaiskloonit. Kloonit valittiin pääsadon kokonaissulavuuden ja satotason perustella ja ne jaettiin valittaessa kolmeen sulavuudeltaan poikkeavaan ryhmään (hyvät, keskimääräiset ja heikot). Lisäksi kontrollikoejäseninä oli Iki ja Grindstad. Koeruudut perustettiin kesällä 2007 kolmena kerranteena. Ruutuihin kylvettiin suojakasvi (timotei) siten, että keskelle jäi metrin pituinen ja kaksi kylvöriviä leveä kylvämätön kohta, johon timoteikloonien pottitaimet istutettiin (2 riviä noin $10 \mathrm{~cm}$ välein). Nurmivuosina 2008 ja 2009 koeruudut saivat sekä keväällä että jälkisadolle $100 \mathrm{~kg} \mathrm{ha}^{-1} \mathrm{~N}$ sekä suositusten mukaisen P- ja K- lannoituksen. Pääsadon näytteenkeruu suoritettiin, kun D-arvon arvioitiin olevan $680-700 \mathrm{~g} \mathrm{~kg}^{-1} \mathrm{ka}$. Jälkisadon korjuu ajoittui tästä 7-8 viikon päähän. Ruutusato korjattiin näytteenottokehikon avulla $3 \mathrm{~cm}$ sänkeen siten, että näytteeksi saatiin kaksi kylvöriviä yhden metrin matkalta. Tämän jälkeen suojakasvi niitettiin $7 \mathrm{~cm}$ sänkeen. Näytteet punnittiin, ja osa näytteestä fraktioitiin vastaavalla tavalla kuin timotein ja ruokonadan kenttäkokeessa. Loput näytteestä punnittiin ja kuivattiin kokonaisnäytteeksi. Kokonaisnäytteistä ja fraktioista analysoitiin OAS, D-arvo, N, kuitu, ligniini ja iNDF NIRS-menetelmällä (Boreal Kasvinjalostus Oy).

\section{Tilastolliset analyysit}

Molempien kokeiden tulokset analysoitiin varianssianalyysillä (ANOVA) käyttäen SAS:n Mixed Model -proseduuria. Data oli epätasapainoinen biologisista syistä: kaikkia versotyyppejä ei esiintynyt kaikissa niittoajankohdissa, jonka vuoksi osassa tuloksia tyydytään julkaisemaan vain käsittelykeskiarvot ja keskivirheet. Samasta syystä varianssianalyysi suoritettiin niitoittain. Yksinkertaisuuden vuoksi tässä kirjoituksessa tarkastellaan etupäässä tuloksia yli korjuuaikojen niittojen sisällä. Eliittiklooniaineiston varianssianalyysissä käytettiin tarvittaessa rikkakasvipitoisuutta kovariaattina. Nurmisadon ravitsemuksellisen arvon ja nurmen muiden ominaisuuksien välisiä suhteita analysoitiin korrelaatioanalyysillä.

\section{Tulokset ja tulosten tarkastelu}

Timotei ja ruokonata poikkesivat sadon ominaisuuksiltaan ja kasvutavaltaan lähes kaikissa suhteissa (Taulukko 1). Pääsadossa molemmat lajit tuottivat keskimäärin yhtä suuren sadon mutta jälkisadossa ruokonadan hyvä jälkikasvu tuli esille. Timoteilla lehtien osuus sadosta oli selvästi pienempi kuin ruokonadalla, etenkin pääsadossa. Tämä johtui suurelta osin siitä, että timotein sadossa korrellisten versotyyppien osuus oli hallitseva (GEN ja ELONG); ruokonadan sato koostui lähes täysin VEGversoista. ELONG-versojen suuri osuus on sinänsä merkittävä havainto: yleensä tämän versotyypin olemassaoloa ei mainita nurmikirjallisuudessa, vaikka jo Davies (1988) ja Höglind ym. (2005) ovat maininneet kyseisen versotyypin olemassa olon ikään kuin erikoistapauksena. Tätä vastoin tutkimuksemme osoittaa, että tämä versotyyppi on itse asiassa oleellinen osa timotein sadonmuodostusta (tästä aiemmin: Pakarinen ym. 2008). GEN-versojen esiintyminen timoteikasvuston jälkisadossa osoittaa selvästi, että timotei tarvitsee kukinnan induktioon vain pitkän päivän, kun taas ruokonata tarvitsee myös vernalisaation (Heide 1984; tästä tarkemmin: Seppänen ym. 2010). Maan pintaa pitkin korjatun ruokonadan sadosta varsin suuri osa oli lehtituppea (ts. pseudokortta) vaikka sato koostuikin lähes täysin VEG-versoista. Käytännön niitossa lehtien osuus on luonnollisesti korkeampi.

Kuolleen solukon osuudessa ei ollut lajien välistä eroa, mutta se oli jälkisadossa selvästi korkeampi kuin pääsadossa. Timotei sisälsi yleisesti vähemmän kivennäisiä mutta enemmän ligniiniä ja iNDF-kuitua kuin ruokonata. Kasvilajeilla on selvä ero iNDF:ligniini -suhteessa: ruokonadalla yksi g ligniiniä sitoo selvästi enemmän NDF:ää sulamattomaan muotoon kuin timoteillä. Erityisen selvä kasvilajiero havaittiin lehtien iNDF:Ligniini -suhteessa: timoteilla se oli 0,8 (SEM 0,03) ja 1,0 (SEM 
0,04) pää- ja jälkisadoissa, kun ruokonadalla vastaavat suhteet olivat 3,7 (SEM 0,20) ja 3,9 (SEM 0,28 ). Tämän perusteella olisi kiinnostavaa verrata tarkemmin ligniinin anatomista rakennetta ja kemiallista koostumusta näiden kahden kasvilajin välillä. Niittojen välinen ero oli selvin versojakaumassa, mutta myös jälkisadon OAS ja D-arvo olivat alhaisemmat kuin pääsadossa. Tämä ei kuitenkaan näkynyt lainkaan ligniinipitoisuudessa eikä kovin selvästi iNDF- tai iNDF:ligniini suhteessa (Taulukko 1).

Koska kuolleen solukon osuus sadossa oli merkittävä, analysoitiin myös sen ravitsemuksellinen laatu. Havaintoja oli käytettävissä kuitenkin epäsymmetrisesti, sillä kuolleen solukon määrä vaihteli korjuukerroittain, joten sen ravitsemuksellinen laatu analysoitiin kerranteet tai korjuuajat yhdistäen. Näin ollen vertailu tyydyttiin tekemään vain keskiarvotarkasteluna (Taulukko 2.). Kuolleen solukon kivennäis-, NDF-, ligniini- ja iNDF-pitoisuudet olivat korkeammat kuin elävän solukon ja vastaavasti RV, OAS, ja D-arvo olivat alhaisemmat, erityisesti jälkisadossa erot olivat huomattavat.

Taulukko 1. Timotein (Tammisto II) ja ruokonadan (Retu) satoparametreja pää- ja jälkisadossa vuosina 2006 ja 2007. Varianssianalyysin käsittelykeskiarvot yli vuosien, niittoaikojen ja versotyyppien. Sato sisältää kuolleen solukon. SEM = ANOVA keskivirhe.

\begin{tabular}{|c|c|c|c|c|c|c|c|c|}
\hline & Pääsato & & & & Jälkisato & & & \\
\hline & Timotei & $\begin{array}{l}\text { Ruoko } \\
\text {-nata }\end{array}$ & SEM & $\begin{array}{l}\mathrm{P}- \\
\text { arvo }\end{array}$ & Timotei & $\begin{array}{l}\text { Ruoko- } \\
\text { nata }\end{array}$ & SEM & $\begin{array}{l}\mathrm{P}- \\
\text { arvo }\end{array}$ \\
\hline Sato, kg ka ha ${ }^{-1}$ & 5250 & 4950 & 162 & 0,13 & 3090 & 3750 & 146 & 0,08 \\
\hline Versotiheys, kpl m² & 2620 & 3050 & 229 & 0,097 & 2620 & 2570 & 114 & 0,75 \\
\hline Lehtien osuus, \% & 24 & 49 & 0,8 & 0,002 & 40 & 53 & 1,3 & 0,016 \\
\hline VEG-versojen osuus, \% & 2 & 84 & - & - & 53 & 100 & - & - \\
\hline ELONG-versojen osuus, \% & 27 & 1 & - & - & 41 & 0 & - & - \\
\hline GEN-versojen osuus, \% & 70 & 15 & - & - & 6 & 0 & - & - \\
\hline Kuolleen solukon osuus, \% & 14,6 & 17,1 & 0,88 & 0,17 & 25,6 & 24,1 & 1,43 & 0,55 \\
\hline Tuhka, g kg ${ }^{-1}$ ka & 73 & 102 & 1,7 & 0,003 & 80 & 104 & 1,6 & 0,005 \\
\hline OAS, g kg-1 oa & 692 & 727 & 2,5 & 0,003 & 677 & 684 & 3,7 & 0,24 \\
\hline D-arvo, g kg ${ }^{-1} \mathrm{ka}$ & 641 & 653 & 3,4 & 0,037 & 624 & 615 & 3,7 & 0,14 \\
\hline Ligniini, g kg ${ }^{-1} \mathrm{ka}$ & 40 & 20 & 0,8 & 0,003 & 35 & 21 & 0,5 & 0,002 \\
\hline iNDF, $\mathrm{g} \mathrm{kg}^{-1} \mathrm{ka}$ & 106 & 88 & 2,7 & 0,038 & 101 & 96 & 2,8 & 0,29 \\
\hline iNDF:ligniini-suhde & 2,6 & 4,3 & 0,1 & 0,008 & 2,9 & 4,7 & 0,14 & 0,012 \\
\hline
\end{tabular}

Taulukko 2. Timotein (Tammisto II) ja ruokonadan (Retu) elävän ja kuolleen solukon ravitsemuksellinen arvo vuosina 2006 ja 2007 (keskiarvo \pm keskivirhe). Keskiarvot on laskettu yli vuosien, kasvilajien, korjuuaikojen ja versotyyppien. $\mathrm{n}$ = havaintojen lukumäärä. Näytteet leikattu maanpintaa myöten.

\begin{tabular}{lcccc}
\hline & Pääsato & \multicolumn{3}{c}{ Jälkisato } \\
\hline $\begin{array}{l}\text { Kuiva-aineessa, } \\
\text { kg }^{-1} \text { ka }\end{array}$ & $\begin{array}{c}\text { Elävä solukko } \\
\text { (kaikki } \\
\text { versotyypit) }\end{array}$ & $\begin{array}{c}\text { Irrallinen kuollut } \\
\text { solukko }\end{array}$ & $\begin{array}{c}\text { Elävä solukko } \\
\text { (kaikki } \\
\text { versotyypit) }\end{array}$ & $\begin{array}{c}\text { Irrallinen } \\
\text { kuollut } \\
\text { solukko }\end{array}$ \\
\hline $\mathrm{n}$ & 101 & 8 & 65 & 8 \\
Tuhka & $84 \pm 1,5$ & $118 \pm 20,5$ & $74 \pm 2,6$ & $130 \pm 28,4$ \\
Raakavalkuainen & $111 \pm 2,7$ & $95 \pm 4,6$ & $113 \pm 5,8$ & $82 \pm 4,8$ \\
OAS (g/kg oa) & $711 \pm 4,2$ & $655 \pm 7,3$ & $706 \pm 4,5$ & $538 \pm 11,4$ \\
D-arvo & $650 \pm 3,4$ & $577 \pm 12,9$ & $653 \pm 3,4$ & $469 \pm 20,7$ \\
NDF & $601 \pm 4,0$ & $674 \pm 18,6$ & $565 \pm 5,0$ & $681 \pm 17,3$ \\
Ligniini & $31 \pm 0,9$ & $48 \pm 4,2$ & $28 \pm 1,0$ & $50 \pm 2,2$ \\
iNDF & $95 \pm 3,1$ & $224 \pm 18,4$ & $74 \pm 2,5$ & $247 \pm 19,5$ \\
iNDF:ligniini-suhde & $3,3 \pm 0,12$ & $4,8 \pm 0,39$ & $3,0 \pm 0,17$ & $5,0 \pm 0,38$ \\
\hline
\end{tabular}


Yleisesti nurmikasvisadon ravitsemuksellinen arvo on sitä korkeampi mitä enemmän sato sisältää lehtiä. Kun tarkasteltiin korrelaatiokertoimia nurmisadon D-arvon ja lehtevyyden välillä huomattiin, että tämä piti paikkansa etenkin pääsadossa (Taulukko 3). Toisaalta kuolleen solukon osuus ei juurikaan korreloinut sadon D-arvon kanssa. Sen sijaan jälkisadossa tilanne oli päinvastainen: kuolleen solukon osuus korreloi selvemmin sadon D-arvon kanssa (negatiivisesti) kuin lehtien osuus (positiivinen korrelaatio). Korrelaatiokertoimet laskettiin vuosittain, sillä vuosi 2006 oli hyvin kuiva ja lämmin kesä-heinäkuun vaihteesta alkaen, ja kuolleen solukon muodostuminen oli suurta heti pääsadon niiton jälkeen. Vuosi 2007 oli lämpötilaltaan normaali, mutta heinäkuun sademäärä oli huomattavasti keskiarvoa korkeampi ja siten kuollutta solukkoa muodostui myöhemmin kun vuonna 2006. Säteilyn ja päiväpituuden laskiessa elokuussa nopeasti voikin olettaa kuollutta kasvustoa syntyvän valokilpailun tuloksena: pienet versot ja alalehdet kuolevat heikentyneiden valo-olosuhteiden vuoksi ja kuolleessaan ne muodostavat karikekerroksen kasvuston juurelle. Sen hajoamisprosessin nopeus riippuu vallitsevasta kosteudesta ja lämpötilasta. Siten on loogista, että erilaiset olosuhteet vaikuttavat myös kuolleen solukon sadon D-arvoa alentavaan vaikutukseen. Koska näytteet otettiin maan pintaa myöten, on kuolleen solukon osuus aineistossa todennäköisesti suurempi kuin käytännön viljelyssä. Kuitenkin myös Sairasen ym. (2010) mukaan normaaliin korkeuteen korjatussa timoteinurminata seoksessa kuollutta solukkoa oli loppukesän niitoissa merkittävästi (12 - 18 \% kuivaaineesta). Laidunkasvustoissa kuolemisprosessia on tutkittu runsaasti (Parsons 1989, Mingo \& Oesterheld 2009), mutta säilörehunurmissa prosessi on selvästi erilainen, eikä tuloksia juuri ole julkaistu. Parhaiten tunnetaan lehtien ontologinen ikä, eli lehdillä on tietty raja (joko vuorokausina tai astepäiväsummina), jonka jälkeen ne kuolevat myös sisäisten prosessien tuloksena (Belanger 1996, Virkajärvi \& Järvenranta 2001). Tutkimusta tulisi laajentaa säilörehunurmien jälkisatoihin, etenkin pohjoisilla leveysasteilla, missä päivän pituuden ja auringon tulosäteilyn muutokset ovat nopeita.

Taulukko 3. Timotein (Tammisto II) ja ruokonadan (Retu) lehtien ja kuolleen solukon osuuden korrelaatiokertoimet $(\mathrm{P}<0,05)$ sadon $\mathrm{D}$-arvon kanssa vuosina 2006 ja 2007. Näytteet leikattu maanpintaa myöten.

\begin{tabular}{|c|c|c|c|c|c|}
\hline & & \multicolumn{2}{|c|}{ Pääsato } & \multicolumn{2}{|c|}{ Jälkisato } \\
\hline Vuosi & Kasvilaji & $\begin{array}{l}\text { Lehtien } \\
\text { osuus }\end{array}$ & $\begin{array}{l}\text { Kuolleen } \\
\text { solukon } \\
\text { osuus }\end{array}$ & $\begin{array}{l}\text { Lehtien } \\
\text { osuus }\end{array}$ & $\begin{array}{l}\text { Kuolleen } \\
\text { solukon } \\
\text { osuus }\end{array}$ \\
\hline 2006 & $\begin{array}{l}\text { Timotei } \\
\text { Ruokonata }\end{array}$ & $\begin{array}{l}0,95 \\
0,89\end{array}$ & $-0,69$ & & $\begin{array}{l}-0,77^{\mathrm{a}} \\
-0,83\end{array}$ \\
\hline 2007 & $\begin{array}{l}\text { Timotei } \\
\text { Ruokonata }\end{array}$ & $\begin{array}{l}0,63 \\
0,69\end{array}$ & & 0,64 & $\begin{array}{l}-0,84 \\
-0,74\end{array}$ \\
\hline Kaikki & $\begin{array}{l}\text { Timotei } \\
\text { Ruokonata }\end{array}$ & 0,47 & & 0,57 & $-0,73$ \\
\hline
\end{tabular}

a) Korrelaatio kiinnittyneen kuolleen kanssa; irrallisen kuolleen korrelaatio NS (P=0,37)

Koska vain timoteissä esiintyi ELONG-versoja, verrattiin kaikkien kolmen versotyypin ominaisuuksia toisiinsa ilman ruokonataa (Taulukko 4). Ensinnäkin oli selvää, että versotyyppi oli oleellinen verson sadontuottokyvyn kannalta: korrellisten versojen paino oli moninkertainen VEG-versoihin nähden ja GEN-versot olivat vielä ELONG-versoja suurempia. Pääsadossa GEN-versojen sato oli suurin. Jälkisadossa VEG- ja ELONG-versojen sato oli yhtä suuri, kun taas GEN-versoja oli vain vähän ja niiden osuus sadosta jäi pieneksi yksittäisen verson suuresta koosta huolimatta. Koska VEG- ja ELONG-versojen kasvupisteet olivat vegetatiivisia, tuottivat ne jatkuvasti uusia lehtiä, mikä näkyi niiden GEN-versoja korkeampana lehtien osuutena. ELONG-verson korsiosuus alensi luonnollisesti lehtien osuutta verrattuna VEG-versoihin. Versojen sadontuottokyky ja menestyminen kilpailussa kasvuston sisällä näkyi myös lehtien kasvunopeudessa (määritetty vain jälkisadosta) ja versoissa vielä kiinni olevan kuolleen solukon määrässä: korrelliset versot poikkesivat selvästi vegetatiivisista ja lehtien kasvunopeudessa, GEN-versot vielä enemmän kuin ELONG-versot. Versojen D-arvojen ero oli pääsadossa melko pieni, kun sitä tarkasteltiin yli niittoaikojen, mutta ELONG- ja GEN-versojen sulavuus laski luonnollisesti korsiintumisen ja korren lignifikaation ansiosta nopeasti, kun taas VEG- 
versojen D-arvo säilyi korkeana. Sen sijaan jälkisadossa VEG- ja ELONG-versojen D-arvo oli keskimäärin korkein ja GEN-versojen matalin. Tämän ilmiön takana oli sekä ELONG-versojen korkea lehtiosuus että niiden korsiosuuden korkeampi sulavuus (Korren D-arvot: ELONG 661 vs GEN 603 g $\mathrm{kg} \mathrm{ka}^{-1}, \mathrm{P}=0.009$ ). Koska havaintoaineistona oli Tammisto II-timotei, on tuloksia tarkasteltaessa muistettava, että versotyyppien erojen selittäjänä voi olla myös kasviyksilöiden perimä, sillä lajike on populaatio, jonka yksilöt voivat poiketa toisistaan genotyyppinsä puolesta.

Eliittiklooniaineistossa eri kloonit poikkesivat toisistaan lähes kaikkien ominaisuuksien suhteen (Taulukko 5). Koska kloonit oli istutettu pottitaimina, eivät ensimmäisen vuoden pääsadon tulokset välttämättä kuvaa parhaalla tavalla kloonien ominaisuuksia. Kloonien väliset erot pysyivät kohtuullisen samankaltaisina yli vuosien, joten versotyyppijakaumaa voidaan pitää sinänsä geneettisenä ominaisuutena. Koska käytetyt koeruudut olivat hyvin pienikokoisia, olivat kuivaainesadon keskivirheet suuria, mutta D-arvon, lehtien osuuden, ja versotyyppijakauman tarkkuus oli varsin hyvä. Näin ollen voidaan päätellä, että satofysiologian keinoin määritettyjä parametrejä on mahdollista hyödyntää timotein jalostuksessa seulottaessa ns. eliittigenotyyppejä.

Taulukko 4. Yhteenveto timotein (Tammisto II) versotyyppien eroista pää- ja jälkisadoissa vuosina 2006 ja 2007.

\begin{tabular}{|c|c|c|c|c|c|c|c|c|c|c|}
\hline & & & Pääsatc & & & & & Tälkisat & & \\
\hline & VEG & ELONG & GEN & SEM & $\mathrm{P}$ & VEG & ELONG & GEN & SEM & $\mathrm{P}$ \\
\hline $\begin{array}{l}\text { Verson paino, } \\
\text { mg ka/verso }\end{array}$ & 31 & 158 & 554 & 12 & $<0,001$ & 81 & 280 & 952 & 62 & $<0,001$ \\
\hline Sato, kg ka/ha & 80 & 1230 & 3250 & 95 & $<0,001$ & 950 & 1030 & 170 & 109 & $<0,001$ \\
\hline $\begin{array}{l}\text { Lehtien osuus } \\
\text { ka:sta }\end{array}$ & 0,54 & 0,36 & 0,24 & 0,02 & $<0,001$ & 0,65 & 0,45 & 0,12 & 0,03 & $<0,001$ \\
\hline $\begin{array}{l}\text { Lehtien kasvu, } \\
\text { mm/vrk/verso }\end{array}$ & - & - & - & - & - & 3,8 & 9,2 & 15,3 & - & - \\
\hline $\begin{array}{l}\text { Kuolleen } \\
\text { osuus, g/kg ka }\end{array}$ & 220 & 80 & 40 & 24 & 0,004 & 130 & 50 & 30 & 13 & $<0,001$ \\
\hline $\begin{array}{l}\text { Verson D- } \\
\text { arvo, g/kg ka }\end{array}$ & 663 & 648 & 652 & 1,4 & 0,003 & 666 & 668 & 630 & 5,8 & $<0,001$ \\
\hline
\end{tabular}

*nettokasvunopeus = bruttokasvu - kuoleminen, määritetty vain 2 sadosta. Ilmiö hyvin epälineaarinen, joten tässä vain keskiarvot ilman tilastollista testausta.

Taulukko 5. Yhteenveto timotein eliittiklooniaineiston sadontuotto- ja laatuominaisuuksien sekä versotyyppiosuuksien eroista vuosina 2008 ja 2009. Varianssianalyysin P-arvot niitoittain ja kokonaissadon osalta. OAS = orgaanisen aineen sulavuus

\begin{tabular}{lllllllll}
\hline & KA-sato & $\begin{array}{l}\text { Lehtien } \\
\text { osuus }\end{array}$ & $\begin{array}{l}\text { VEG } \\
\text { osuus }\end{array}$ & $\begin{array}{l}\text { ELONG } \\
\text { osuus }\end{array}$ & $\begin{array}{l}\text { GEN } \\
\text { osuus }\end{array}$ & OAS & D-arvo & RY-sato \\
\hline Pääsato 2008 & 0,185 & 0,009 & 0,70 & 0,47 & 0,55 & $<0,001$ & 0,001 & 0,234 \\
Pääsato 2009 & $<0,001$ & $<0,001$ & 0,31 & 0,005 & 0,007 & $<0,001$ & $<0,001$ & $<0,001$ \\
Jälkisato 2008 & $0,2072^{\mathrm{a}}$ & $<0,001$ & $<0,001$ & $0,030^{\mathrm{a}}$ & $0,007^{\mathrm{a}}$ & 0,001 & 0,028 & $0,379^{\mathrm{a}}$ \\
Jälkisato 2009 & $<0,001^{\mathrm{a}}$ & $<0,001$ & $<0,001^{\mathrm{a}}$ & $0,004^{\mathrm{a}}$ & $0,001^{\mathrm{b}}$ & 0,008 & $0,036^{\mathrm{a}}$ & $<0,001^{\mathrm{a}}$ \\
Kokonaissato 2008 & $0,391^{\mathrm{a}}$ & - & - & - & - & - & - & $0,54^{\mathrm{a}}$ \\
Kokonaissato 2009 & $<0,001^{\mathrm{a}}$ & - & - & - & - & - & - & $<0,001^{\mathrm{a}}$ \\
\hline
\end{tabular}

${ }^{\mathrm{a}}$ Käytetty rikkakasvipitoisuutta kovariaattina. ${ }^{\mathrm{b}}$ Käytetty neliöjuurimuunnosta.

Kloonit oli valittu siten, että ne edustivat joko poikkeuksellisen sulavia, keskinkertaisia tai poikkeuksellisen heikosti sulavia genotyyppejä. Valinta oli tehty pääsadon tulosten perusteella. Kun laskettiin korrelaatio sulavuuden ja kuiva-ainesadon välille, saatiin näkyviin klassinen negatiivinen korrelaatio (Kuva 1). Valintaperuste näkyi siten, että pääsadossa etukäteen poikkeuksellisen sulaviksi arvioidut kloonit olivat keskimääräisen trendisuoran yläpuolella ja etukäteen heikoiksi arvioidut olivat suoran alapuolella. Kun sama analyysi tehtiin jälkisadosta, huomattiin, että ryhmien sijainti kuvassa muuttui. Lisäksi nähtiin, että sekä vuonna 2008 että 2009 yksi poikkeavan satoisa timotei (Grindstad) 
aiheutti pääosan korrelaatiosta, eikä havaittu negatiivinen korrelaatio ollut muutenkaan kovin vahva. Eri genotyyppien välinen ero D-arvossa oli varsin suuri, etenkin jälkisadossa. Näyttää siltä, että timotein sadon laatua säätelevät eri tekijät pää- ja jälkisadoissa.

Erityisesti timoteikloonien jälkisadon VEG-versojen suuri osuus paransi D-arvoa, mutta alensi voimakkaasti sadon määrää; GEN-versot vaikuttivat päinvastoin. ELONG-versot olivat molempien ominaisuuksien suhteen melko neutraaleja. ELONG-versojen suuri osuus voi liittyä valokilpailuun. Koska timoteikasvustossa esiintyy korkeita GEN-versoja (myös syksyllä), jäävät ei-korrelliset VEGversot kasvuston alaosaan ja GEN-versojen varjostamiksi. Siten niiden uudet lehdet syntyvät alhaisen säteilyn oloissa, mikä johtaa niiden heikkoon fotosynteesikapasiteettiin ja luonnollisesti myös alhaiseen fotosynteesiin (Parsons 1988). Jos tällainen vegetatiivinen verso pystyy kasvattamaan korren, se pystyy nostamaan syntyvät uudet lehdet kasvuston pintakerrokseen ja saa siten kilpailuedun valon suhteen, vaikka ei tekisikään kukintoa. ELONG-versot tarjoavat siten otollisen kohteen korren kasvun ja sadonmuodostuksen sekä korren lignifikaation ja rehulaadun välisten yhteyksien tutkimiselle.
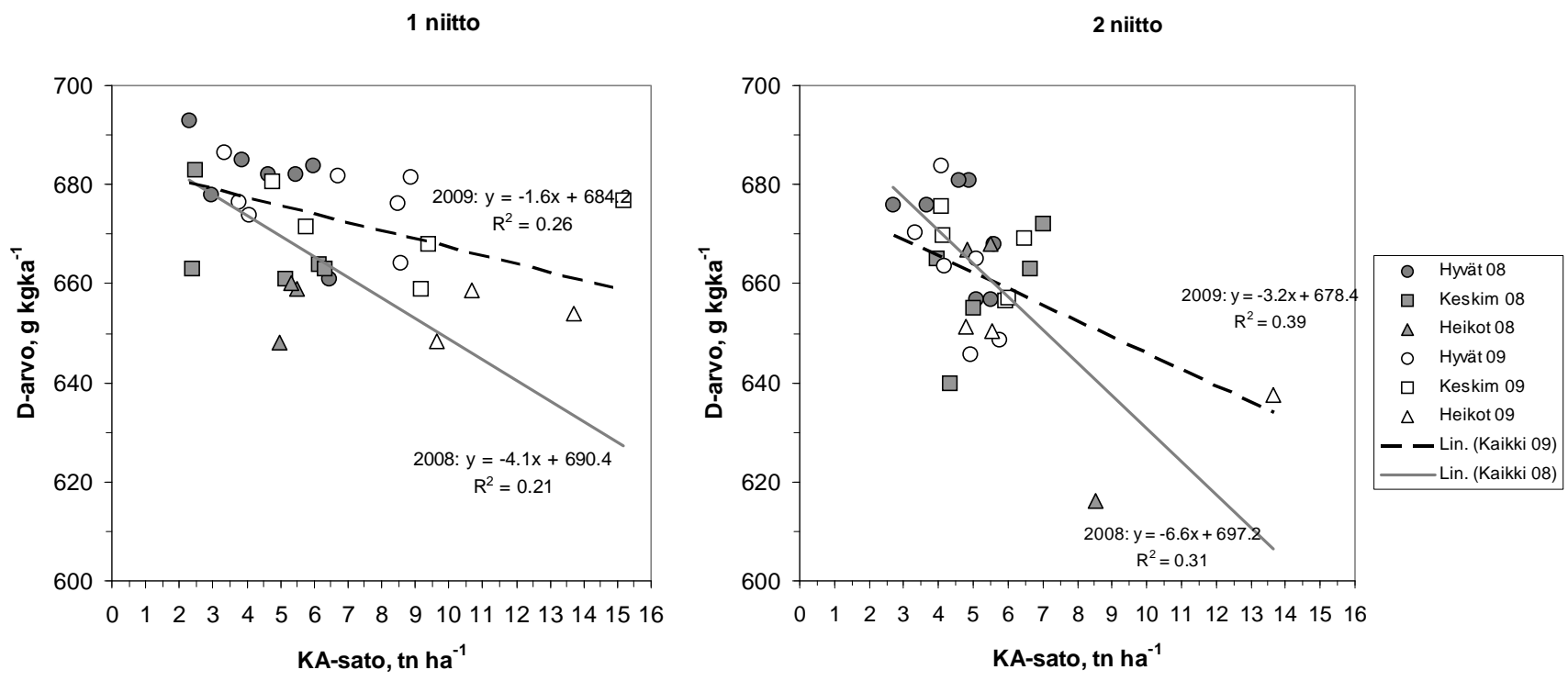

Kuva 1. Timotein eliittikloonien sadon ja D-arvon yhteys pää- ja jälkisadossa (niitot 1 ja 2) vuosina 2008 ja 2009. Kloonit jaettu valittaessa kolmeen sulavuudeltaan poikkeavaan ryhmään (hyvät, keskimääräiset ja heikot).

\section{Johtopäätökset}

Nurmien satofysiologian tunteminen auttaa ymmärtämään nurmisadon laatuun ja määrään vaikuttavia syitä. Keskeiset nurmen kasvuprosessit sadonmuodostuksen ja laadun kehityksen osalta ovat korrenmuodostus, versominen ja solukkojen kuolema. Timoteillä ja ruokonadalla nämä prosessit poikkeavat toisistaan lähes kaikkien sadonmuodostus- ja laatuominaisuuksien osalta. Ruokonadan ja timotein erot iNDF:ligniini-suhteessa ovat potentiaalinen tutkimuskohde selvitettäessä ligniinin rakentumisen vaikutusta rehun sulavuuteen. Timotein ELONG-versot ovat merkittävä osa timotein sadonmuodostusta. Versotyyppien erot tarjoavat hyvän tutkimuskohteen selvitettäessä korrenmuodostukseen ja solukkojen kuolemaan liittyviä prosesseja. Timoteistä on mahdollista seuloa satofysiologisia parametrejä käyttämällä ns. eliittigenotyyppejä, joiden sadonmuodostus ja laatu ovat erityisen suotuisia.

\section{Kirjallisuus}

Belanger, G. 1996. Morphogenetic and structural characteristics of field-grown timothy cultivars differing in maturity. Canadian Journal of Plant Science 76: 277-282. 
Davies, A. 1988. The regrowth of grass swards. Teoksessa: Jones, M.B. \& Lazenby, A. (toim). The grass crop. The physiological basis of production. s. 85-128. Chapman \& Hall, London. 369 s.

Höglind, M., Hanslin, H. M. \& van Oijen, M. 2005. Timothy regrowth, tillering and leaf area dynamics following spring harvest at two growth stages. Field Crops Res. 93, 51-63.

Heide, O. 1994. Control of flowering and reproduction in temperate grasses. New Phytologist 128: 347-362.

Mingo, A. \& Oesterheld, M. 2009. Retention of dead leaves by grasses as a defense against herbivores. A test on the palatable grass Paspalum dilatum. Oikos 118:753-757.

Nousiainen, J., Rinne, M., Hellämäki, M. \& Huhtanen, P. 2003. Prediction of the digestibility of the primary growth of grass silages harvested at different stages of maturity from chemical composition and pepsincellulase solubility. Animal Feed Science and Technology 103: 97-111.

Pakarinen, K., Virkajärvi, P., Seppänen, M., Rinne, M. 2008. In: Hopponen, A. (toim.) Suomen maataloustieteellisen seuran tiedote no 23: Maataloustieteen Päivät 2008, 10.-11.1.2008 [esitelmät ja posterit] Verkkojulkaisu. http://www.smts.fi/mpol2008/index.htm. 5 s.

Parsons, A. 1988. The effects of season and management on the growth of grass swards. Teoksessa Jones, M.B. \& Lazenby, A. (toim). The grass crop. The physiological basis of production. s. 129-178. Chapman \& Hall, London. $369 \mathrm{~s}$.

Sairanen, A. , Virkajärvi, P., Juutinen, E. 2010. Karjatilan nurmirehun korjuuaikastrategiat. Maataloustieteen Päivät 2010. Saatavilla Internetissä: www.smts.fi

Seppänen, M. Pakarinen, K., Jokela, V., Santanen, A., Virkajärvi, P. 2010. Timotein kukintaan virittyminen ja sen yhteys korren laatuominaisuuksiin Maataloustieteen Päivät 2010. Saatavilla Internetissä: www.smts.fi

Virkajärvi, P. \& Järvenranta, K. 2001.Leaf dynamics of timothy and meadow fescue under Nordic conditions. Grass and Forage Science 56: 294-304. 